\title{
Clinical Review: management of Lower respiratory tract infection in pediatric
} population

\author{
Ghasna Mohiuddin ${ }^{1}$, Syed Wasif Gillani ${ }^{2 *}$, Anam Azhar ${ }^{1}$, Rukhsar A. Majeed ${ }^{1}$
}

\author{
${ }^{1}$ Pharm D candidate, College of Pharmacy Gulf Medical University, Ajman, UAE \\ ${ }^{2}$ Assoc. Prof. Department of Pharmacy Practice, College of Pharmacy Gulf Medical University, Ajman, UAE
}

\author{
Received: 02 October,2019 \\ Accepted: 09 December,2019 \\ *Correspondence to: \\ Dr. Syed Wasif Gillani, PhD \\ Email: dr.syedwasif@gmu.ac.ae
}

Copyright: (C) the author(s), publisher and licensee Indian Academy of Pharmacists. This is an open-access article distributed under the terms of the Creative Commons Attribution Non-Commercial License, which permits unrestricted non-commercial use, distribution, and reproduction in any medium, provided the original work is properly cited.

Published by: OZZIE Publishers

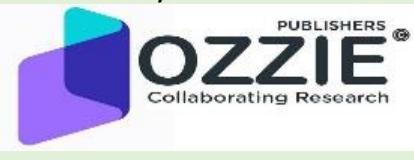

\section{Abstract}

Objective: The aim of this clinical review was to have an in-depth knowledge of the antibiotics being used to treat lower respiratory tract infections which are most likely to occur in the pediatric population of different age groups. Methods: This study analyzed 43 articles which were studied and identified according to the research criteria. The required data has been searched using research gate, ncbi, Medscape, Mayo Clinic, WebMD. Results: The findings included different levels of effectiveness in the 5 generations of cephalosporin's as some killed certain bacteria's better than others and are relatively short acting with half-life of about 30-120 minutes when compared to penicillin. For example, first generation cephalosporin's were quite active against gram positive bacteria when compared to gram negative bacteria however, the efficacy was reduced due to resistance. It was discussed regarding second generations that they are effective against both gram negative and gram-positive bacteria and are resistant to Blactamase more than the first generations, therefore have a high anti-bacterial activity. As far as the third and fourth generations were concerned, they were able to penetrate the blood-brain barrier and were frequently designed for bacterial meningitis which were caused by susceptible pathogens. Fifth generations have a similar mechanism of action as that of the $3^{\text {rd }}$ generations and can treat resistant staphylococcus aureus and streptococcus species which are resistant to penicillin antibiotics. On the other hand, Carbapenems (penetrates bacterial cell wall of micro-organisms and inhibits cell wall synthesis) and aminoglycosides (inhibits protein synthesis by binding to bacterial ribosomes and inducing misreading of the of the genetic code) are one of the most highly efficacious as they prevent severe and high risk bacterial infections although, rare incidents of toxicity and life threatening side effects have been reported when taken aminoglycosides. Conclusion: Penicillin is the safest to treat and prevent the lower respiratory tract infections in the pediatric population as they have minor side effects such as headache, nausea compared to other antibiotics.

Keywords: Lower respiratory tract infections, Cephalosporin, Pediatrics, Carbapenems, Aminoglycoside, Drug resistance, dose, pharmacokinetics, Gram negative bacteria, Gram positive bacteria.

\section{INTRODUCTION}

Lower respiratory tract infections are usually caused by bacteria and virus. The pediatric population is observed to be the most susceptible to it as the antibiotics are not used properly thus leading to resistance (1) LRTIs can be divided into pneumonia, chronic bronchitis and acute exacerbations of chronic obstructive pulmonary disease $(2,3)$. These infections can affect people of all age, but mostly its children who are likely to suffer (3). It has also been statistically proven that around $13 \%$ of all infectious illnesses are in infants younger than 2 years (4).

The respiratory rate thresholds displayed by World Health Organization for children with this infection are as follows: Children younger than 2 months have greater than or equal to 60 beats per minute, Children aged between 2-11 months show greater than or equal to 50 breaths per minute, and children aged around 1-3 years have greater than or equal to 40 breaths per minute (5)

Congestion, fever and irritability are a few signs and symptoms of LRTI (4) Various tests were taken into consideration to diagnose this particular infection, for example: Auscultation by stethoscope, cultures, complete blood cell count (CBC) and chest radiography \& Ultrasonography (3).

A broad spectrum of antibiotics was used to treat lower respiratory tract infections. High-dose amoxicillin is used as a first line (5). Combination therapy (ampicillin and either gentamicin or cefotaxime) is typically used in the initial treatment of newborns and young infants (4).Carbapenems (Blactams), are one of the safest as it has the least side-effects, however the frequent use of it can lead to resistance $(6,7)$. The time period, drug which is administered, and the strength of 
the dose can vary depending on different factors such as the patient's age, etc. (8). Cephalosporin's are the other class of drugs used in children, which includes 4 generations (9). This class of the drug is one of the most effective when it comes to the bacteria which has been exposed for long as it inhibits bacterial cell wall synthesis. (10) Third generation cephalosporin's are less effective against gram positive cocoa when compared to gram negative rods. However, they are the most used at they are effective in treating bacterial meningitis in children (2).

First generation of cephalosporins: Cephalexin Cephalexin belongs to the first class of cephalosporins with the chemical name,7-(D-a-amino -a-phenylacetamido)-3methyl-3-cephem-4-carboxylic acid, and it is related to cephaloglycin.

Cephalexin is a known bactericidal antibiotic (11). It is a white crystalline compound with high solubility hence orally administered (12). It gets easily dissolved in $2 \mathrm{mg} / \mathrm{ml}$ distilled water at room temperature (14). It's not effected by plasma protein significantly hence it is excreted without any metabolical changes.

The in vitro antimicrobial functioning of cephalexin is not equivalent to the in vitro activity of cephaloglycin. (11) Cephalexin is very quickly solubilized but it's binding sites available are not sufficient hence, balances out low in vitro antimicrobial activity. (13) When comparing the lab activity of cephaloglycin, tetracyclin and chloramphenicol with cephalexin, cephalexin gave much better results when the same procedure was carried out on mice with bacterial infection $(11,14)$

A clinical study was carried out on 12 people, 6 males and 6 females, all of them being healthy individuals. The age of these samples units was between 20 and 41 years, weight of these individuals between 52.5 and $76 \mathrm{~kg}$ where mean weight $=67.8 \mathrm{~kg}$. All of these volunteers did not have any medication for past 14 days. The results obtained were as such: there was a rapid increase to the average peak concentration of $38.8 \pm$ $8.1 \mathrm{mg} /$ liter (averaging 55.5 $+21.8 \mathrm{~min}$ ). And also relatively a very rapid reduction to just $1.2 \mathrm{mg} /$ liter after 6 hours, culminating in a biological half-life of $62.5 \pm 5.5 \mathrm{~min}$ (13)

Second generation of cephalosporins: Cefoxitin

Cefoxitin is a 8-lactam cephamycin antibiotic, injectable. It's administration is either intravenously or intramuscularly(16). It is usually preferred for pediatric population as it has high antibacterial activity(16). In vitro studies show it's high effectiveness on many common pathogens usually found in pediatrics(17). Cefoxitin is used for bacteriae like: Streptococcus pneumonia, Streptococcus aureus, Haemophilus influenzae etc(17). it's acts by absorbing onto the proteins therefore inhibiting the cell wall functioning such as synthesis but its activity is highly dependent on the kind of organism and where it is present because that determines how well it can be absorbed hence the dose strength is determined(18).

A study was carried out on 32 infants ranging from 3 month old to 26 month old and the recorded results were shown in figure 1 (19):

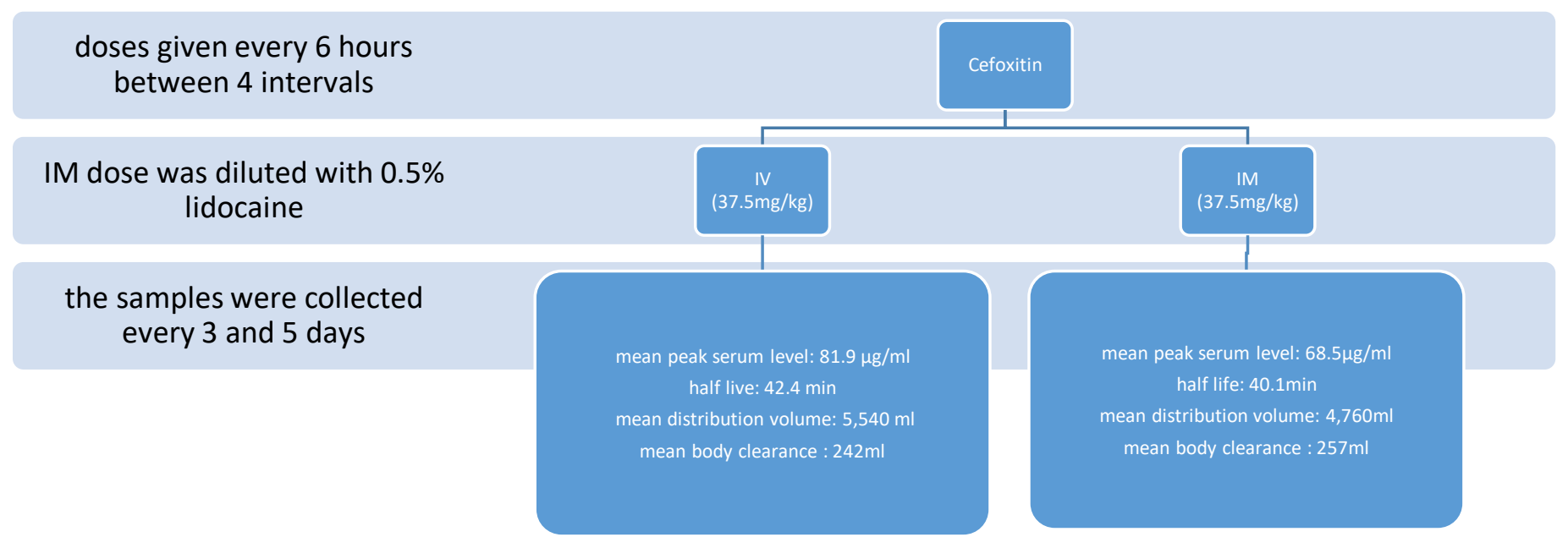

Figure 1: Results of administration of Cefoxitin to 32 infants.

For checking how efficient cefoxitin is, regular tests are done on patients as well as healthy individuals as references and bacterias are extracted before they are administered with any kind of medications, antibiotics specifically, and cultured and examined(19).
The most appropriate dose for treatment is $80-160 \mathrm{mg} / \mathrm{kg}$ for infants ( 3 months old) but this should be given in small quantities such as, this dose can be given 4 or 6 times rather than 1 or 2(19). But if the infection is very severe, the dose can be increased but total intake of the drug should not exceed $12 \mathrm{~g}(19)$. 
Table 1: Summary of the $3^{\text {rd }}$ generation cephalosporins used in pediactric population for LRTIs.

\begin{tabular}{|c|c|c|c|c|c|c|c|c|c|}
\hline Generic name & $\begin{array}{l}\text { Therapeutic } \\
\text { Use }\end{array}$ & Dose & \multicolumn{2}{|c|}{ Absorption } & Distribution & Metabolism & \multicolumn{2}{|c|}{ Elimination } & Excretion \\
\hline Cefpodoxime & $\begin{array}{l}\text { Acute } \\
\text { Community- } \\
\text { Acquired } \\
\text { Pneumonia }\end{array}$ & $\begin{array}{l}>12 \text { years } \\
200 \mathrm{mg} \text { PO } \\
\text { q12hr for } 14 \\
\text { days. }\end{array}$ & \multicolumn{2}{|c|}{$\begin{array}{l}\text { BA: } 50 \%, \text { acid } \\
\text { stable. } \\
\text { Peak plasma time: } \\
\leq 1 \mathrm{hr}\end{array}$} & $\begin{array}{l}\text { Distributed well } \\
\text { into tissues, also } \\
\text { lungs and } \\
\text { tonsils; } \\
\text { penetrates into } \\
\text { pleural fluid. } \\
\text { Protein } \\
\text { bound:18-23\% }\end{array}$ & $\begin{array}{l}\text { Metabolized in } \\
\text { liver to active } \\
\text { metabolite }\end{array}$ & \multicolumn{2}{|c|}{$\begin{array}{l}\text { Half-life: } 2-3 \\
\text { hr; prolonged } \\
\text { with renal } \\
\text { impairment }\end{array}$} & $\begin{array}{l}\text { Urine ( } 80 \% \text { as } \\
\text { unchanged drug) } \\
\text { in } 24 \mathrm{hr}\end{array}$ \\
\hline $\begin{array}{l}\text { Cefotaxime } \\
(25,35)\end{array}$ & Pneumonia & $\begin{array}{l}<12 \text { years or } \\
<50 \mathrm{~kg}: 200 \\
\mathrm{mg} / \mathrm{kg} / \mathrm{day} \\
\text { IV divided } \\
\text { q8hr } \\
>12 \text { years or } \\
>50 \mathrm{~kg}: 1-2 \\
\mathrm{~g} \mathrm{IV} / \mathrm{IM} \\
\text { q } 8 \mathrm{hr} .\end{array}$ & \multicolumn{2}{|c|}{$\begin{array}{l}\text { Peak plasma time: } \\
\text { IM, } 30 \text { min }\end{array}$} & $\begin{array}{l}\text { widely } \\
\text { distributed to } \\
\text { body tissues and } \\
\text { fluids, including } \\
\text { aqueous humor, } \\
\text { ascitic and } \\
\text { prostatic fluids, } \\
\text { bone, penetrates } \\
\text { CSF when } \\
\text { meninges } \\
\text { inflamed }\end{array}$ & $\begin{array}{l}\text { Partially } \\
\text { metabolized in } \\
\text { liver } \\
\text { Metabolite: } \\
\text { Desacetylcefotaxi } \\
\text { me (active) }\end{array}$ & \multicolumn{2}{|c|}{$\begin{array}{l}\text { Half-life: } \\
\text { Parent drug, 1- } \\
1.5 \text { hr; active } \\
\text { metabolite, 1- } \\
1.9 \mathrm{hr}\end{array}$} & Urine. \\
\hline \multirow{2}{*}{$\begin{array}{l}\text { Ceftazidime } \\
(27)\end{array}$} & \multirow[b]{2}{*}{$\begin{array}{l}\text { Hospital } \\
\text { acquired } \\
\text { pneumonia } \\
\text { (HAP) and } \\
\text { Community } \\
\text { acquired } \\
\text { pneumonia } \\
\text { (CAP) }\end{array}$} & \multirow[b]{2}{*}{$\begin{array}{l}\text { If child is } 4 \\
\text { weeks - } \\
30 \mathrm{mg} / \mathrm{kg} \\
\text { every } \\
\text { 12Hours } \\
\text {-If child is } 1 \\
\text { month -12 } \\
\text { y/o- } 30 \text { to } \\
50 \mathrm{mg} / \mathrm{kg} \\
\text { every } 8 \\
\text { hours. } \\
(28,30)\end{array}$} & IV & IM & \multirow[b]{2}{*}{$\begin{array}{l}\text { aqueous } \\
\text { humour, bile, } \\
\text { blister } \\
\text { fluid,bone, } \\
\text { bronchial } \\
\text { secretions, CSF, } \\
\text { abcess, } \\
\text { myeometrium } \\
\text { e.t.c } \\
\text { Protein binding : } \\
5-24 \% \text {. } \\
(31)\end{array}$} & \multirow[b]{2}{*}{$\begin{array}{l}\text { not metabolized } \\
\text { by the liver and as } \\
\text { a result its } \\
\text { clearance and } \\
\text { elimination from } \\
\text { the body is solely } \\
\text { dependent on the } \\
\text { RENAL } \\
\text { SYSTEM. } \\
\text { (29) }\end{array}$} & IV & IM & \multirow[b]{2}{*}{$\begin{array}{l}\text { A } 24 \text { hour } \\
\text { urianalysis } \\
\text { showed that } \\
89 \% \text { of drugs } \\
\text { was recovered } \\
\text { unchanged. }\end{array}$} \\
\hline & & & $\begin{array}{l}\text { Peak } \\
\text { concentr } \\
\text { ation } \\
\text { after IV } \\
\text { administr } \\
\text { ation was } \\
109 \mathrm{mg}\end{array}$ & $\begin{array}{l}\text { Peak } \\
\text { conce } \\
\text { ntratio } \\
\mathrm{n} \text { after } \\
\mathrm{IM} \\
\text { admini } \\
\text { stratio } \\
\mathrm{n} \text { was } \\
53 \mathrm{mg}\end{array}$ & & & $\begin{array}{l}\mathrm{T} 1 / \\
2 \text { of } \\
4.17\end{array}$ & $\begin{array}{l}\mathrm{T} 1 / 2 \text { of } \\
3.8\end{array}$ & \\
\hline$\frac{\text { Ceftibuten }}{(32,33,34)}$ & Bronchitis & $\begin{array}{l}12 \text { years or } \\
\text { older: } 400 \\
\text { mg orally } \\
\text { once a day } \\
\text { for } 10 \text { days }\end{array}$ & \multicolumn{2}{|c|}{$\begin{array}{l}\text { Rapid; food } \\
\text { decreases peak } \\
\text { concentrations, } \\
\text { delays Tmax, and } \\
\text { lowers AUC. } \\
\text { peak time: } 2 \text { to } 2.6 \\
\text { hours }\end{array}$} & $\begin{array}{l}\text { Distributes into } \\
\text { middle ear fluid, } \\
\text { bronchial } \\
\text { secretions, and } \\
\text { sputum. Protien } \\
\text { binding: } \\
65 \%\end{array}$ & $\begin{array}{l}\text { predominantly } \\
\text { eliminated } \\
\text { through kidney in } \\
\text { the pediatric } \\
\text { population. }\end{array}$ & \multicolumn{2}{|c|}{$\begin{array}{l}\text { Half life } \\
\text { elimination: } \\
\text { Children: } 2 \\
\text { hours; }\end{array}$} & $\begin{array}{l}\text { Urine }(56 \%) \text {; } \\
\text { feces }(39 \%)\end{array}$ \\
\hline
\end{tabular}

Acute Lower respiratory tract infections occur very often in children. Until now penicillin and related drugs are the most commonly used in pediatric population for treatment of these infections. The mainstream use of penicillin and it's derivatives has led to penicillin resistant strains of Streptococcus pneumonia(23) and beta-lactamase-producing strains of Haemophilus influenza(23) and Moraxella catarrhalis(23). It is a matter of concern because about 4

Figure 2: Graphical presentation of comparative study of two successful antibiotics for LRTIs in peadiatrics. Pathogens separated from 59 cases included $H$. influenzae (47.5\%), S. pneumoniae (23.7\%), M. catarrhalis (11.9\%) and million deaths due to these infections are otherwise preventable hence, physicians are now progressively using other substitutes such as third generation cephalosporins. (23) A third-generation cephalosporin, cefpodoxime proxetil has a broader spectrum and it is also active against the bacterias responsible for LRTIs in children. A study was done to assess its clinical effectiveness in children with acute febrile LRTIs as shown in figure 2. (23)

Haemophilus parainfluenzae (6.8\%). There was no difference in bacteriologic efficacy of the two treatments, and both drugs were well-tolerated. Thus, cefpodoxime proxetil is highly effective and well-tolerated in childhood pneumonia and is at least as effective as the comparator drug. (23). 


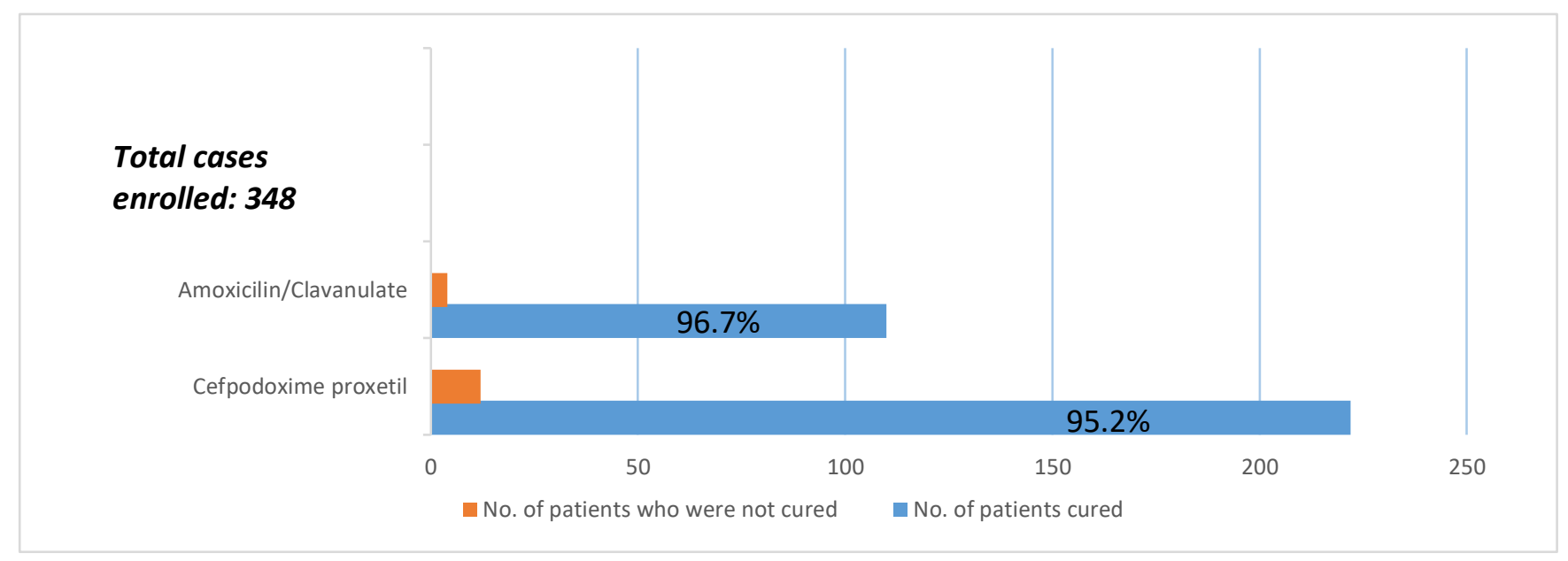

Figure 2: Graphical presentation of comparative study of two successful antibiotics for LRTIs in peadiatrics

Fourth generation of cephalosporins: Cephalosporins, Cefepime, Maxipime

Maxipime is a semi-synthetic cephalosporin antibacterial whose route of administration is usually parenteral (20). Maxipime is used to treat moderate Pneumonia triggered by Streptococcus Pneumonia, Klebsiella Pneumonia, Pseudomonas aeruginosa or Enterobacter species (20). Maxipime can slow down the progression of resistance of the bacteria towards the drugs and also maintain the effect of maxipime and also other drugs used to treat (20). When treating with maxipime, epidemiological conditions and also the patterns (if available) should be looked into (20).

These drugs are used for pediatric populations, so a study was carried out on 88 patients who were treated with cefepime(14). The age of these patients was between 2 months old to 26 years old (14). Cefepime was administered through IV route and IM route (15). Single IV dose, multiple IV doses and IM doses (15). In all the patients, after steady dosages, 2 days later urine or CSF samples were collected (15). In all the results collected cefepime was observed to be decreasing sometime after and when multiple doses were given, no significant improvement in the results hence proving that the dose is independent of any parameter (15). The results were as listed in table 2(15):

Table 2: Results from urine or CSF sample collected from patients administered cefepime.

For moderate to severe pneumonia, the dose prescribed should be $50 \mathrm{mg} / \mathrm{kg}$ every 8 hours (17).

Cefepime was well absorbed when given through IM route and

- Mean (range) parameters observed in this review were: $\mathrm{t} 1 / 2=1.7 \mathrm{~h}$ (1.26 to 1.93$)$

- Volume of distribution at steady state: 0.37 liter/ $\mathrm{kg}$ (0.33 to 0.40 )

- Total body clearance: $3.1 \mathrm{ml} / \mathrm{min} / \mathrm{kg}(1.43$ to 4.01 )

it also penetrated into CSF in patients suffering from bacterial meningitis, differentiated with beta lactams $(14,17)$.

Fifth generation of cephalosporins: Ceftaroline
Ceftaroline is a fifth-generation cephalosporin antibiotic. It acts by preventing the production of cell wall (B-lactamase) (21). They adsorb on the surface of PBP-2a, manufactured by MRSA and PBP-2a which is synthesized by penicillin resistant Streptococcus pneumonia (22). It has high activity on gram positive and gram negative (22). It is used to treat skin infections (also bacterial infections on the skin) triggered by MRSA and many common pathogens (23).

Ceftaroline is a prodrug and it has to be metabolised to convert it into its active form (21). It is metabolised by phosphate enzymes, the drug is later hydrolysed to inactive form (21). It is usually administered by injections, it is highly effected by the strength of the drug, as stronger the dose higher the Cmax concentration as well as AUC (21). the drug is recommended for regular use for fourteen day but not more than 14 because if used for fourteen days at regular intervals the drug shows no complications in any of the body compartments, metabolism and excretion is controlled well as the drug as low affinity towards proteins hence less binding (22). The approved doses are as shown in table 3 (22):

Table 3: Ceftaroline doses based on age and weight of the child.

\begin{tabular}{|l|l|}
\hline Age/weight & Dose \\
\hline $\begin{array}{l}\text { Neonates and infants younger than } 2 \\
\text { months }\end{array}$ & $6 \mathrm{mg} / \mathrm{kg}$ every $8 \mathrm{hr}$ \\
\hline 2 months to less than 2 years old & $8 \mathrm{mg} / \mathrm{kg}$ every $8 \mathrm{hr}$ \\
\hline 2 years old and above & $12 \mathrm{mg} / \mathrm{kg}$ every $8 \mathrm{hr}$ \\
\hline Weight less than $33 \mathrm{~kg}$ & $400 \mathrm{mg}$ every $8 \mathrm{hr}$ \\
\hline Weight more than $33 \mathrm{~kg}$ & $600 \mathrm{mg}$ every $12 \mathrm{hr}$ \\
\hline
\end{tabular}

If the patient has cystic fibrosis, it will have an impact on ceftroline as its pharmacokinetics in the body as it enhances the mean clearance level and also ellivated the total distribution volume throughout the body, reason being malnutrition and less deposition in the adipose tissues hence decreasing the total drug concentration in the body(20). A study was carried on a six year old child sufering from cystic fibrosis and another six year old healthy chiild who does not have any other health issues (21). The child suffering from cystic fibrosis has shown some improvement clinically but 
there is a risk of child gaining the resistance towards the drug hence the drug cannot be used for a long term(21).

Ceftaroline was tested randomly as well as controlled experiments were done on children from the age of six months to 24 months and then it was approved by the ABSSI and CABP for pediatric population (under the age of two months)(22). Ceftaroline is not considered to be the first choice of drug but later when FDA approved it to be a bactericidal it is considered to be a good alternative option(24). Some common Side effects of ceftaroline are rashes, fever, gastrointestinal irritation and also the effects it causes(25).

\section{Carbapenams :}

Carbapenams are of the traditional antibiotics which are given by IV and have a time duration of 15-60 minutes (36). They are used to treat a variety of diseases, for example, nosocomial pneumonia, community acquired and pseudomonas infections in cystic fibrosis which are very severe and needs treatment before the condition worsens. (38) When you compare the structures of penicillin and carbapenams, they are quite similar except the fact that the sulfur atom is replaced by a carbon atom at position one and are therefore classified as beta lactam antibiotics, and play a role against both gram positive and negative bacteria. (7) Carbapenams are time-dependent antibiotics as they kill the bacteria when the drug concentration is above the minimum concentration required to cause an inhibitory effect (MIC). (41)

Carbapenems mode of action initiates as they move through the bacterial wall and binds to penicillin binding proteins (enzyme) (37) Transpeptidase is the main target enzyme of carbapenams during bacterial cell wall synthesis. (40) A covalent bond is formed by penicillin-binding proteins which consists of carboxypeptidase and transpeptidase enzyme. (7) This helps in preventing the cross-linkage of peptides during peptidoglycan biosynthesis, therefore resulting in cell apoptosis within the bacterial cell (41). Table 4 gives us detailed knowledge of the dose, excretion and the distribution of various type of carbapenems (6)

Table 4: Recommended dose according to the child's age and their respective pharmacokinetic data.

\begin{tabular}{|c|c|c|c|c|}
\hline Drug & Pediatric Age & $\underline{\text { Dose }}$ & Excretion & $\underline{\text { Distribution }}$ \\
\hline \multirow[t]{4}{*}{ Imipenem/cilastatin } & $\begin{array}{l}\text { Newborns }(<1 \\
\text { week) }\end{array}$ & $\begin{array}{l}25 \mathrm{mg} / \mathrm{kg} \text { every } 12 \\
\text { hours }\end{array}$ & \multirow{4}{*}{$\begin{array}{c}\text { Clearance rate: } \\
2.3-6 \mathrm{ml} / \mathrm{kg} / \mathrm{min} \\
\text { Half-life: } 1-3 \text { hours }\end{array}$} & \multirow[t]{4}{*}{$\begin{array}{c}\mathrm{Vd}=0.36- \\
0.67 \mathrm{~L} / \mathrm{kg}\end{array}$} \\
\hline & 1-4 weeks & $\begin{array}{l}25 \mathrm{mg} / \mathrm{kg} \text { every } 8 \\
\text { hours }\end{array}$ & & \\
\hline & $1-3$ months & $\begin{array}{l}25 \mathrm{mg} / \mathrm{kg} \text { every } 6 \\
\text { hours }\end{array}$ & & \\
\hline & $\begin{array}{l}3 \text { months and } \\
\text { above }\end{array}$ & $\begin{array}{l}15-25 \mathrm{mg} / \mathrm{kg} \text { every } \\
6 \text { hours }\end{array}$ & & \\
\hline \multirow[t]{3}{*}{ Meropenem } & Neonates & $\begin{array}{l}20 \mathrm{mg} / \mathrm{kg} \text { every } \\
12 \text { hours } \\
40 \mathrm{mg} / \mathrm{kg} \text { every } 8 \\
\text { hours for } \\
\text { meningitis }\end{array}$ & \multirow{3}{*}{$\begin{array}{l}\text { Clearance rate: } 1.8- \\
5.63 \mathrm{ml} / \mathrm{kg} / \mathrm{min} \\
\underline{\text { Half-life: } 1-3 \text { hours }}\end{array}$} & \multirow{3}{*}{$\begin{array}{l}\mathrm{Vd}=0.43- \\
0.48 \mathrm{~L} / \mathrm{kg}\end{array}$} \\
\hline & $\begin{array}{l}3 \text { months and less } \\
\text { than } 50 \mathrm{kgs}\end{array}$ & $\begin{array}{l}20 \mathrm{mg} / \mathrm{kg} \text { every } \\
8 \mathrm{hours} \\
40 \mathrm{mg} / \mathrm{kg} \text { every } 8 \\
\text { hours for } \\
\text { meningitis }\end{array}$ & & \\
\hline & $\begin{array}{l}\text { More than or } \\
\text { equal to } 50 \mathrm{kgs}\end{array}$ & $\begin{array}{l}1 \mathrm{~g} \text { every } 8 \\
\text { hours } \\
2 \mathrm{~g} / \text { dose for } \\
\text { meningitis } \\
\end{array}$ & & \\
\hline \multirow[t]{2}{*}{ Ertapenem } & 3months-12 years & $\begin{array}{l}15 \mathrm{mg} / \mathrm{kg} \text { every } 12 \\
\text { hours }\end{array}$ & \multirow{2}{*}{$\begin{array}{l}\text { Clearance rate: } \\
2.1-3.3 \mathrm{ml} / \mathrm{kg} / \mathrm{min} \\
\text { Half-life: } 2.5-4 \\
\text { hours }\end{array}$} & \multirow[b]{2}{*}{$\mathrm{Vd}=0.2 \mathrm{~L} / \mathrm{kg}$} \\
\hline & $\begin{array}{l}\text { More than or } \\
\text { equal to } 1 \text { year }\end{array}$ & 1 day every day & & \\
\hline \multirow[t]{2}{*}{ Doripenem } & $\begin{array}{l}3 \text { months to less } \\
\text { than } 2 \text { years }\end{array}$ & $\begin{array}{l}10 \mathrm{mg} / \mathrm{kg} \text { every } 8 \\
\text { hours }\end{array}$ & \multirow{2}{*}{$\begin{array}{l}\text { Clearance: } 3.1- \\
6.5 \mathrm{ml} / \mathrm{kg} / \mathrm{min} \\
\frac{\text { Half-life: } 0.9-1.1}{\text { hours }}\end{array}$} & \multirow[b]{2}{*}{$\begin{array}{l}\mathrm{Vd}=0.22- \\
0.46 \mathrm{~L} / \mathrm{kg}\end{array}$} \\
\hline & $\begin{array}{l}\text { More than or } \\
\text { equal to } 2 \text { years }\end{array}$ & $\begin{array}{l}15 \mathrm{mg} / \mathrm{kg} \text { every } 8 \\
\text { hours }\end{array}$ & & \\
\hline
\end{tabular}

Bronchitis and pneumonia are the two major types of acute lower respiratory tract infections which increase the death rate in children under 5 years of age. (1) The most common pathogen was Staphylococcus aureus (which had affected infants with lower respiratory tract infections) streptococcus pneumonia and E.coli which was treated using Methicillin. E.coli showed less resistance to cephalosporin's compared to other antibiotics such as piperacillin and ampicillin. Aminoglycosides were however contraindication to be used for children as they caused major sideeffects such as hearing loss and achondroplasia $(40,41)$

Staphylococcus aureus causes $25 \%$ of community acquired pneumonia cases. Mostly, the cases are related to skin and soft tissue infection.In addition to this, socioeconomic factors such as low income, poor lifestyle, limited health care due to insufficient breast feeding and other reasons such as air pollution therefore causing these 
respiratory tract infections to become acute (8) However, more research has been conducted which suggests that antenatal care and routine immunization can help prevent diseases and save many lives (39)

Beta-lactamase are the enzymes which are produced by bacteria that causes resistance to some antimicrobials and can degrade $\beta$-lactam antimicrobials. (38) However, carbapenems which contains $\beta$-lactamase inhibitors cannot be degraded so easily (40). Carbapenems can cause hepatotoxicity when jaundice occurs as they have an insignificant hepatic metabolism effect (37). This is a very rare condition caused by carbapenems but should be taken into consideration when giving it to children. (41)
An enzyme, called dehydropeptidase-1 (DHP-1) is located in the renal tubules which allows most of the carbapenams to be broken down. (36) Due to this reason, it is advised for carbapenems to be administered with cilastatin which is a DHP-1 inhibitor. (38) The potency of such antibiotics is reduced due to increased resistance and other cost containment issues. (41) If the dose carbapenems is not taken with complete cautious, it gives rise to other several issues leading to more resistant organisms. (37)

\section{Penicillins and Aminoglycosides}

Table 5 summarises the mechanism of action, dose, absorption, distribution, metabolism and excretion of penicillins and aminoglycosides.

Table 5: Pharmacokinetic data of Penicillin and it's derivatives, and Aminoglycosides.

\begin{tabular}{|c|c|c|c|}
\hline & Amoxicillin (43) & Ampicillin (42) & Penicillin (42) \\
\hline Mechanism of Action & $\begin{array}{l}\text { It has a bactericidal property- } \\
\text { meaning it kills the bacterial } \\
\text { growth by disrupting cell } \\
\text { wall synthesis of } \\
\text { mucopeptides when the } \\
\text { bacterial cell is actively } \\
\text { multiplying }\end{array}$ & $\begin{array}{l}\text { It is a broad-spectrum } \\
\text { penicillin which has similar } \\
\text { MOA to Amoxicillin, it is } \\
\text { used as an alternative to } \\
\text { amoxicillin when the } \\
\text { medication cannot be taken } \\
\text { orally }\end{array}$ & $\begin{array}{l}\text { It impedes cell wall synthesis and has } \\
\text { bactericidal action especially during } \\
\text { active multiplication of the organism. } \\
\text { However, if not given in sufficient doses, } \\
\text { it may produce only bacteriostatic effects. }\end{array}$ \\
\hline Dose & $\begin{array}{l}<3 \text { months: }<30 \mathrm{mg} / \mathrm{kg} / \text { day } \\
\text { PO divided q12hr for } 48-72 \\
\text { hours; for }>10 \text { days for S. } \\
\text { pyogenes infections. } \\
>3 \mathrm{months} \text { and }<40 \mathrm{~kg}: 45 \\
\mathrm{mg} / \mathrm{kg} / \mathrm{day} \text { PO divided q12hr } \\
\text { or } 40 \mathrm{mg} / \mathrm{kg} / \text { day PO divided } \\
\text { q8hr. } \\
>40 \mathrm{~kg}: 875 \mathrm{mg} \text { PO q12hr or } \\
500 \mathrm{mg} \text { PO q } 8 \mathrm{hr} \text { for } 10-14 \\
\text { days }\end{array}$ & $\begin{array}{l}\text { <20 kg: } 50 \mathrm{mg} / \mathrm{kg} / \text { day PO } \\
\text { divided q6-8hr } \\
\text { >20kg: } 250 \mathrm{mg} \text { PO q6hr } \\
\text { <40kg: } 25-50 \mathrm{mg} / \mathrm{kg} / \mathrm{day} \\
\text { IV/IM divided q6-8hr. } \\
\text { >40 kg: } 250-500 \mathrm{mg} \text { IV/IM } \\
\text { q6hr. }\end{array}$ & $250 \mathrm{mg}$ PO q8-12hr for 10 days \\
\hline Absorption & $\begin{array}{l}\text { Bioavailability: } 74-92 \% \\
\text { Peak plasma time: } \\
\text { 2hr(capsule) } \\
3.1 \mathrm{hr} \text { (extended release tab) } \\
1 \mathrm{hr} \text { (suspension). }\end{array}$ & $\begin{array}{l}\text { Bioavailability: } 30-40 \% \\
\text { Peak plasma time: } 1-2 \mathrm{hr} \\
\text { (oral) }\end{array}$ & $\begin{array}{l}\text { Bioavailability: } 60-73 \% \\
\text { Peak plasma time: } 0.5-1 \mathrm{hr}\end{array}$ \\
\hline Distribution & $\begin{array}{l}\text { Most body fluids and bone, } \\
\text { CSF < } 1 \% \\
\text { Protein bound: } 17-20 \%\end{array}$ & $\begin{array}{l}\text { Protein bound: } 15-25 \% \\
\text { Blister and tissue fluids, bile, } \\
\text { nd CSF with inflamed } \\
\text { meninges }\end{array}$ & $\begin{array}{l}\text { Protein bound: } 80 \% \\
\text { Crosses placenta; poor Blood-Brain } \\
\text { Barrier diffusion. }\end{array}$ \\
\hline Metabolism & Hepatic & Hepatic & Hepatic \\
\hline \multirow[t]{2}{*}{ Excretion } & $\begin{array}{l}\text { Excretion in urine } \\
\text { Half-life: } 3.7 \mathrm{hr}(\text { full-term } \\
\text { neonates); } 1-2 \mathrm{hr} \text { (infants and } \\
\text { children). }\end{array}$ & $\begin{array}{l}\text { Excretion in urine }(90 \% \\
\text { within } 24 \mathrm{hr}) \text {. } \\
\text { Half-life: } 1-1.8 \mathrm{hr} \text { (normal } \\
\text { renal function); } 7-20 \mathrm{hr} \\
\text { (anuria/end-stage renal } \\
\text { disease). }\end{array}$ & $\begin{array}{l}\text { Excretion in urine } \\
\text { Half-life: } 0.5-0.6 \mathrm{hr}\end{array}$ \\
\hline & Gentamycin (3) & Amikacin (3) & Tobramycin (5) \\
\hline Mechanism of Action & $\begin{array}{l}\text { It irreversibly binds to } \\
\text { specific } 30 \text { S-subunit proteins } \\
\text { and } 16 \mathrm{~S} \text { rRNA (specifically } \\
\text { binds to four nucleotides of } \\
16 \mathrm{~S} \text { rRNA and a single } \\
\text { amino acid of protein } \mathrm{S} 12 \text { ). }\end{array}$ & $\begin{array}{l}\text { Hinders mRNA binding and } \\
\text { tRNA acceptor sites by } \\
\text { binding to bacterial 30S } \\
\text { ribosomal subunits which } \\
\text { results in disrupted normal } \\
\text { protein synthesis and non- } \\
\text { functional or toxic peptides } \\
\text { are produced. As a result, it } \\
\text { interferes with bacterial } \\
\text { growth. }\end{array}$ & $\begin{array}{l}\text { Aminoglycoside has two binding sites on } \\
\text { the } 30 \mathrm{~S} \text { ribosomal subunit, to one of } \\
\text { which tobramycin binds and inhibits } \\
\text { bacterial protein synthesis. Additionally, } \\
\text { tobramycin may also bind to } 16 \mathrm{~S} \text { rRNA } \\
\text { and destabilize bacterial membrane. }\end{array}$ \\
\hline Dose & $\begin{array}{l}\text { (Children, 1year or older) } 6 \\
\text { to } 7.5 \mathrm{mg} / \mathrm{kg} / \text { day IV/IM in } \\
\text { equally divided doses every } 8 \\
\text { hours for } 7 \text { to } 10 \text { days. } \\
\text { (Infants and neonates, } 1 \text { year } \\
\text { or younger) } 7.5 \mathrm{mg} / \mathrm{kg} / \text { day }\end{array}$ & $\begin{array}{l}\text { Neonates: } 10 \mathrm{mg} / \mathrm{kg} \text { IV/IM } \\
\text { loading dose followed with } \\
7.5 \mathrm{mg} / \mathrm{kg} \text { IV/IM every } 12 \\
\text { hours; MAX } 15 \mathrm{mg} / \mathrm{kg} / \text { day } \\
\text { total daily dose. } \\
\text { Infants and children: } 15 \\
\mathrm{mg} / \mathrm{kg} / \text { day IV/IM divided }\end{array}$ & $\begin{array}{l}\text { Premature or full-term neonates, } 1 \text { week } \\
\text { or younger: upto } 4 \mathrm{mg} / \mathrm{kg} / \text { day IV in } 2 \\
\text { equally divided doses every } 12 \text { hours. } \\
\text { Greater than } 1 \text { week of age: } 6- \\
7.5 \mathrm{mg} / \mathrm{kg} / \text { day IV in } 3-4 \text { equally divided } \\
\text { doses every } 6 \text { to } 8 \text { hours. }\end{array}$ \\
\hline
\end{tabular}




\begin{tabular}{|c|c|c|c|}
\hline & $\begin{array}{l}\text { IV/IMequally divided doses } \\
\text { every } 8 \text { hours for } 7-10 \text { days. } \\
\text { (Premature or full-term } \\
\text { neonates, } 1 \text { week or younger) } \\
5 \mathrm{mg} / \mathrm{kg} / \text { day IV/IM in equally } \\
\text { divided doses every } 12 \text { hours } \\
\text { for } 7-10 \text { days. }\end{array}$ & $\begin{array}{l}\text { every } 8-12 \text { hours for } 7-10 \\
\text { days depending on type and } \\
\text { severity of infection; MAX } \\
15 \mathrm{mg} / \mathrm{kg} / \text { day total daily } \\
\text { dose; MAX } 1.5 \mathrm{~g} / \text { day in } \\
\text { heavier patients. }\end{array}$ & \\
\hline Absorption & $\begin{array}{l}\text { Bioavailability, } \\
\text { intraperitonial: } 76 \% \\
\text { Peak plasma time, IM: } 30 \text { to } \\
60 \text { minutes. }\end{array}$ & $\begin{array}{l}\text { Bioavailability IM: } 80-90 \% \\
\text { Peak plasma time IM: } 1 \mathrm{hr} .\end{array}$ & $\begin{array}{l}\text { Bioavailability, IM: rapidly absorbed. } \\
\text { Peak plasma time IM: } 30-90 \text { minutes. }\end{array}$ \\
\hline Distribution & $\begin{array}{l}\text { Protein Binding:0-30\% } \\
\text { VD:0.34 to } 0.46 \mathrm{~L} / \mathrm{kg}\end{array}$ & $\begin{array}{l}\text { Protein Binding: } 0-11 \% \\
\text { VD: } 24 \mathrm{~L} \text { ( } 28 \% \text { of body } \\
\text { weight). }\end{array}$ & $\begin{array}{l}\text { Protein Binding: minimal, if any. } \\
\text { VD: } 0.34-0.645 \mathrm{~L} / \mathrm{kg}\end{array}$ \\
\hline Metabolism & Hepatic, minimal & Hepatic, minimal & Hepatic, minimal \\
\hline Excretion & $\begin{array}{l}\text { Renal excretion: } 65-100 \% \\
\text { Renal clearance: } 99.9 \text { to } \\
136.2 \mathrm{~mL} / \mathrm{min} / 1.73 \mathrm{~m}^{2} . \\
\text { Half-life: } 3.05-3.9 \mathrm{hrs} .\end{array}$ & $\begin{array}{l}\text { Renal excretion: } 84-94 \% \\
\text { unchanged } \\
\text { Half-life: slightly over } 2 \text { hrs. }\end{array}$ & $\begin{array}{l}\text { Renal excretion: upto } 93 \% \\
\text { Half-life: } 3.5-11.28 \text { hours. }\end{array}$ \\
\hline
\end{tabular}

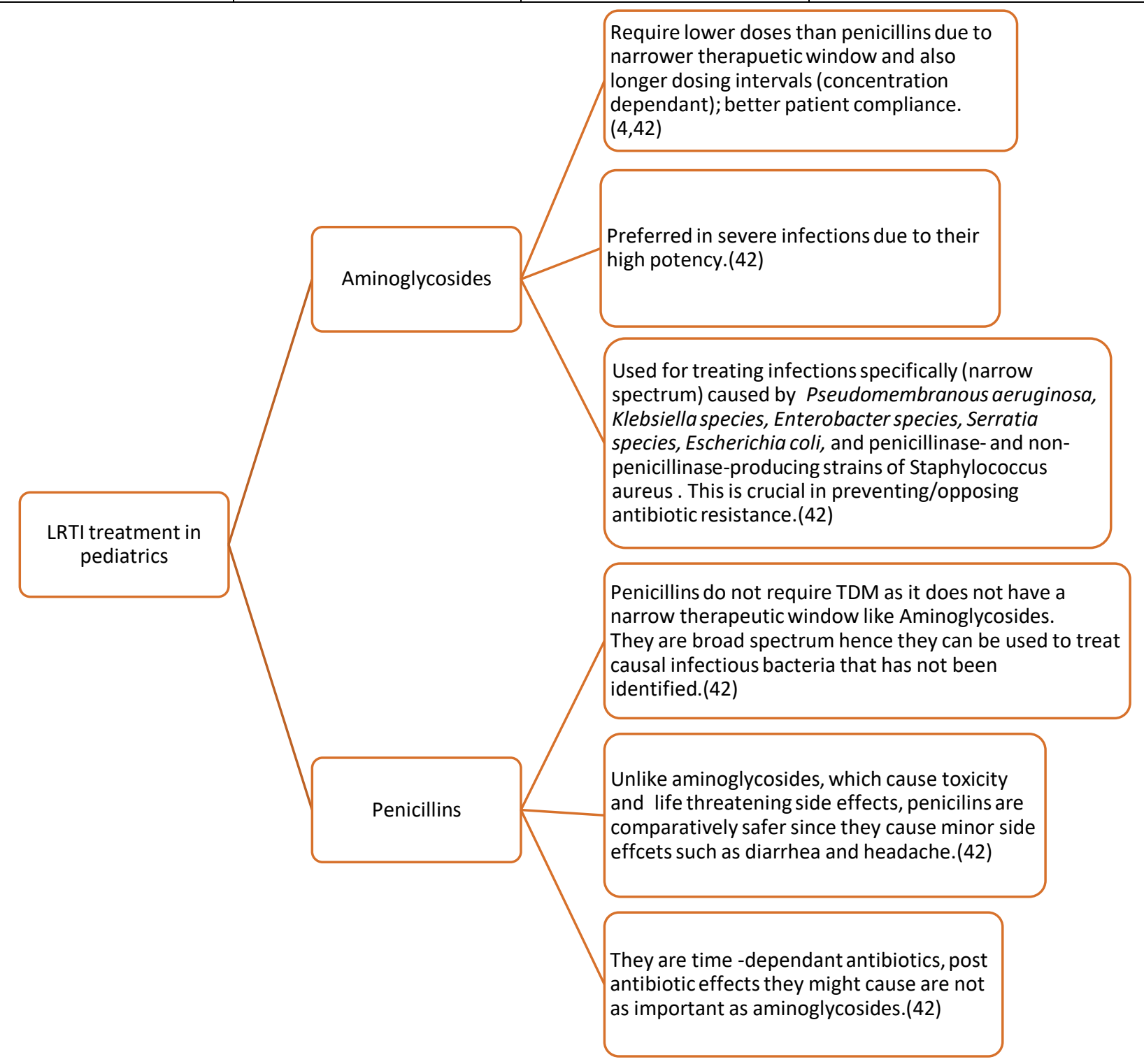

Figure 3: Comparison between penicillin and aminoglycosides' safety and toxicity.

The collected data shown in figure 3 suggests that the best choice of antibiotic in the treatment of LRTI in pediatrics are penicillin's since their efficacy to toxicity balance is better than in aminoglycosides. 


\section{SAFETY MENAMICS}

Penicillin is one of the safest antibiotics which was used as it inhibits different type of bacteria without leading to severe side-effects which would make the condition more severe. Following this cephalosporin's and carbapenems are considered to be beneficial as well. When the 5 generations of cephalosporins are compared, third, fourth and fifth generation agents achieve high concentration in the CSF as it can cross the blood brain barrier successfully and have a tremendous activity against gram negative aerobic bacteria including the pathogens responsible for bacterial meningitis against children compared to the first and the second. However, first generations are potentially useful against mild-moderate infections caused by gram positive bacteria. Aminoglycosides are potent but cause life-threatening side effects so they are the least safe class of antibiotics.

Penicillin > Cephalosporins (Third generation) $>$ Fourth generation $>$ Fifth generation $>$ First generation $>$ Second generation $>$ Carbapenems $>$ Aminoglycosides

\section{CONCLUSION}

This study analysed the effectiveness of different classes of antibiotics which could be used in the treatment of lower respiratory tract infections in the paediatric population. The efficacy, potency, safety and the pharmacokinetics of the antibiotics were the main factors which were taken into consideration when making the suitable choice as children especially infants who have a very sensitive immune system as it is still developing therefore is not completely function. Due to this reason, they are at a very high risk of infection. Aminoglycosides are the most potent hence they're used for very specific infections (narrow spectrum) however, they cause toxicity so TDM is necessary (42). Penicillins on the other hand, are the safest in terms of toxicity since the only reported side effects are diarrhea and headache, but their frequent use, as it is a broad-spectrum antibiotic, has led to resistance (42). The best penicillin class antibiotic is Amoxicillin as it has the highest bioavailability compared to ampicillin and penicillin (43). When comparing the lab activity of cephaloglycin, tetracyclin and chloramphenicol with cephalexin, which is a first-generation cephalosporin gave much better results when the same procedure was carried out on mice with bacterial infection $(11,14)$. Cefoxitin, which is a second-generation cephalosporin is usually preferred for pediatric population as it has high antibacterial activity (16) but dose should be carefully adjusted. For third generation Cephalosporins (Cefpodoxime, Cefotaxime, Ceftazidime and Ceftibuten), Ceftazidime and Ceftibuten are predominantly are eliminated through the renal system hence should be given with care in patients with renal problems (27, 33, 34). Cefepime; $4^{\text {th }}$ generation cephalosporin was well absorbed when given through IM route and it also penetrated into CSF in patients suffering from bacterial meningitis, differentiated with beta lactams $(14,17)$. Ceftaroline $\left(5^{\text {th }}\right.$ generation cephalosporin) has high activity on gram positive and gram negative (22).

Carbepenems are another class of antibiotics that are used to treat a variety of diseases, for example, nosocomial pneumonia, community acquired and pseudomonas infections in cystic fibrosis which are very severe and needs treatment before the condition worsens however, their use is less because bacterias are becoming resistant to it. Additionally,
Carbapenems may sometimes cause hepatotoxicity when jaundice occurs as they have an insignificant hepatic metabolism effect (37) so this should also be considered before using them in children.

\section{REFRENCES}

1. Bushra, Riaz Humera Khatoon. The use of cephalosporin antibiotics in pediatrics. Journal of applied pharmaceutical science 2013; 3(4): 63-66

2. Mohammed Hundu alamari. Lower respiratory tract infection in paediatrics treatment approaches. The Egyptians journal of hospital medicine 2018; 73(3): 63246330.

3. J.M. Lanao et al. Pharmacokinetics of amikacin in children with normal and impaired renal function. Official journal of the international society of nephrology $1981 ; 20(1)$ : 115-121.

4. Nazario D Rivera Chaparro et al. Dosing antibiotics in neonates: Review of the pharmacokinetic data. Future Microbiology 2017; 12(11).

5. Bothra M et al. Tobramycin for the Treatment of Bacterial Pneumonia in Children. Department of Pediatrics (2012); 13(4): 565-71.

6. Aguilera-Alonso D et al. Position statement of the Spanish Association of Paediatrics-Spanish Society of Paediatric Infectious Diseases (AEP-SEIP) on the treatment of Multidrug-resistant bacterial infections. Anales de Pediatría (English Edition) 2003; 91(5):1-13.

7. Blumer JL. Pharmacokinetic determinants of carbapenem therapy in neonates and children. Pediatr Infect Dis J 1996; 15: 733-737.

8. Eric Giannoni et al. Prospective determination of plasma imipenem concentrations in critically ill children. Antimicrob Agents Chemother 2006; 50(7): 2563-2568.

9. Liver Tox: Clinical and Research Information on DrugInduced Liver Injury [Internet]. Bethesda (MD): National Institute of Diabetes and Digestive and Kidney Diseases; 2012-Cephalosporins. Available from: https://www.ncbi.nlm.nih.gov/books/NBK548666/[Updat ed 2017 Jan 9]

10. Charles G. Prober. Cephalosporin's an update. Paediatrics in review (1998); 19(4): 118-127.

11. C.F.Ackman et al. The use of cephalexin in the treatment of gonorrhoea. Canadian Medical Association journal (1972); 106(4): 350-351.

12. Alian Bailey et al. Cephalaxin- A new oral antibiotic. Post grad Med J (1970); 157-158.

13. Wick WE. Cephalexin, a new orally absorbed cephalosporin antibiotic. Appl Microbiol (1967); Jul; 15(4): 765-769.

14. Dafna Yahav. Efficacy and safety of cefepime: a systematic review and meta-analysis. Lancet Infect Dis (2007); 7: 338-48

15. Lode H. Comparative pharmacokinetics of cephalexin, cefaclor, cefadroxil, and CGP 9000. Antimicrob Agents Chemother (1979); 16(1): 1-6.

16. Hirama Y. Some experiences in the field of paediatrics with cefoxitin treatment by intravenous injection. Jpn J Antibiot (1981); 34(3): 244-56. 
17. Olivier C. Clinical use of cefuroxime in paediatric community acquired pneumonia. Department of General Paediatrics 2000; 2(5): 331-43.

18. M. Fassbender et al. Pharmacokinetics of new oral cephalosporin's. Clinical Infectious Diseases (1993); 16(5): 646-653.

19. William E. Feldman et al. Clinical and Pharmacokinetic Evaluation of Parenteral Cefoxitin in Infants and Children. Antimicrobial agents and chemotherapy (1980); 17(4): 669-674.

20. Blumer Jeffreyl et al. Review of the pharmacokinetics of cefepime in children. The Pediatric Infectious Disease Journal (2001); 20(3): 337-342.

21. Bradley JS, Arrieta.A. Emperic use of Cefepime in the treatment of lower respiratory tract infections in children. Pediatr Infect Dis J (2001); 20(3): 343-9.

22. Juwon Yim et al. Use of ceftaroline Fosamil in children: Review of current knowledge and its application. Infectious disease and therapy (2017); 6(1): 55-67.

23. Max Klein. Multicentre trial of cefpodoxime proxetil vs amoxicillin-calvulanate in acute lower respiratory tract infections in childhood. Pediatr Infect Dis J (1995); 14(4): 19-22.

24. BNF. Chapter 18, Prescribing in children (2018); 76: 4445.

25. H.Lode. Role of long acting cephalosporin's in the treatment of lower respiratory tract infections. Department of chest and infectious diseases (2000); 6(3): 87-89.

26. Gian Maria Pacifici. Pharmacokinetics of cephalosporin's in the neonate: A review. Clinics Sao Paulo (2011); 66(7): 1267-1274.

27. Peirce TH. Ceftazidime in the treatment of lower respiratory tract infections. $\mathrm{J}$ antimicrobe chemother (1983); 21-5.

28. IBM Watson Micromedex. Ciftazidime side effects [Internet], www.drugs.com/sfx/ceftazidime-sideeffects.html (2019 Feb 9)

29. Marcia L. Buck. Use of Ciftazidime- Avibactam in infants and children. Pediatric pharmacology (2019); 25(5): $1-4$.

30. IBM Watson Micromedex. Ciftazidime Dosage [Internet] www.drugs.com/dosage/ceftazidime.html (2019 Sep 11)
31. Geneva. Use of ceftazidime in children and options for treating pseudomonas infections. Second Meeting of the Subcommittee of the Expert Committee on the Selection and Use of Essential Medicines (2008); 1-16

32. IBM Watson Micromedex. Ceftibuten Dosage www.drugs.com/dosage/ceftibuten.html [Internet] (2019 Dec 2).

33. Chin-chung Lin et al. Comparative bioavailability of ceftibuten in capsule and suspension form. Clinical therapeutics (1996); 18(6): 1139-1149.

34. Nix DE. Comparative pharmacokinetics of oral ceftibuten, cefixime, cefaclor, and cefuroxime axetil in healthy volunteers (1997); 17(1): 121-5.

35. J B M van Woensal. Viral lower respiratory tract infections in infants and young children. BMJ (2003); 327(7405): 36-40.

36. Patrick M. Grove. Doripenem Use in Pediatrics aâ, $\neg$ "Learning from Pharmacokinetic Data of Other Carbapenems. Journal of pediatrics sciences. 2010; 2: 18.

37. Xiaoguang He. Antimicrobial resistance in bacterial pathogens among hospitalized children with community acquired lower respiratory tract infections in Dongguan, China. BMC infect Dis (2017); 17: 614.

38. Overturf GD. A brief review for paediatric infectious disease specialist. Pediatr Infect Dis J (2010); 29(1): 687

39. Michela Sonego. Risk Factors for Mortality from Acute Lower Respiratory Infections (ALRI) in Children under Five Years of Age in Low and Middle-Income Countries: A Systematic Review and Meta-Analysis of Observational Studies (2015

40. Francis S. Codjoe. Carbapenem resistance: A review. Med sci (Basel) (2018): 6(1).

41. Thomas G Slama. Clinical review: Balancing the therapeutic, safety and economic issues underlying effective antipseudomonal carbapenem use. Critical care (2008); 12(5): 233.

42. Padari H. Pharmacokinetics of Penicillin G in preterm and term neonates. Antimicrobe agents Chemother (2018); 62(5).

43. Tang BH. Population Pharmacokinetics and Dosing Optimization of Amoxicillin. Antimicrob agents chemother (2019); 63(2). 